\title{
INEL BNCT Research Program March/April 1993
}

Edited by

J. R. Venhuizen

Published June 1993

Idaho National Engineering Laboratory EG\&G Idaho, Inc. Idaho Falls, Idaho 83415

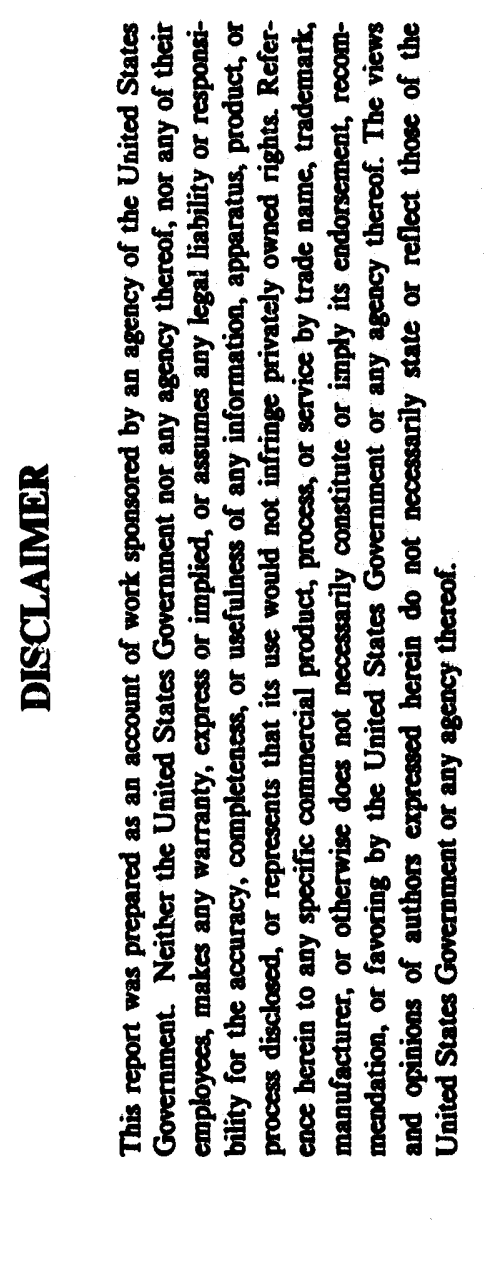

Prepared for the

U.S. Department of Energy Under DOE Field Office, Idaho Contract DE-AC07-761D01570 


\section{ABSTRACT}

This report presents summaries for two months of current research of the Idaho National Engineering Laboratory Boron Neutron Capture Therapy Program. Information is presented on development and murine screening experiments of low-denality lipoprotein, carboranyl alanine, and liposome boron containing compounds. Pituitary tumor cell culture studies are described. Drug stability. pharmacology and toxicity evaluation of borocaptate sodium and boronophenylalanine are described. Treatment protocol development via the large animal (canine) model studies and physiological response evaluation in rats are discussed. Supporting technology development and tochnical support activities for boron drug biochemistry and purity, analytical and measurement dosimetry, and noninvasive boron quantilication activities are included for the current time period. Current publications for the two months are listed. 
ACRONYMS AND ABBREVIATIONS $\ldots \ldots \ldots \ldots \ldots \ldots \ldots \ldots \ldots \ldots \ldots \ldots \ldots$

INTRODUCTION $\ldots \ldots \ldots \ldots \ldots \ldots \ldots \ldots \ldots \ldots \ldots \ldots \ldots \ldots \ldots \ldots \ldots \ldots \ldots$

BORON DRUG DEVELOPMENT $\ldots \ldots \ldots \ldots \ldots \ldots \ldots \ldots \ldots \ldots \ldots \ldots \ldots \ldots$

Carboranyl Alanine and Low-Density Lipoprotein (LDL) Development and Evaluation ... 1

Boronated Liposome Development and Evaluation . . . . . . . . . . . . . . 1

Pituitary Tumor Evaluation $\ldots \ldots \ldots \ldots \ldots \ldots \ldots \ldots \ldots \ldots$

BORON LOCALIZATION SCREENING $\ldots \ldots \ldots \ldots \ldots \ldots \ldots \ldots \ldots \ldots \ldots \ldots \ldots \ldots$

Boronophenylalanine (BPA) Evaluation Studies .................. 2

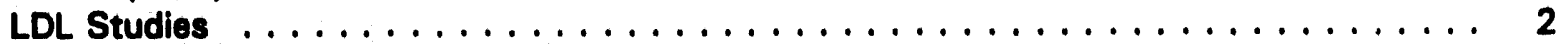

Liposome Evaluation Studies . . . . . . . . . . . . . . . . . . . . 2

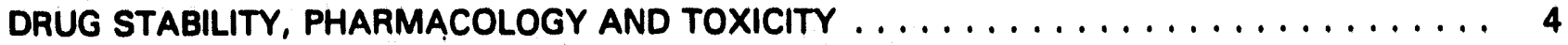

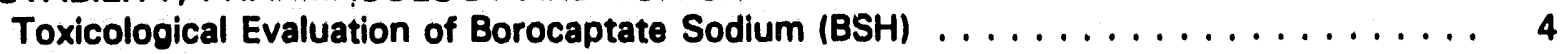

TREATMENT PROTOCOL DEVELOPMENT $\ldots \ldots \ldots \ldots \ldots \ldots \ldots \ldots \ldots$

Large Animal Model Studies . . . . . . . . . . . . . . . . . . . . . . 6

Physiological Response Evaluation and Interdiction . . . . . . . . . . . . 6

SUPPORTING TECHNOLOGY DEVELOPMENT $\ldots \ldots \ldots \ldots \ldots \ldots \ldots \ldots \ldots \ldots \ldots$

Task 1: Biochemistry of BSH and Its Oxidation Products . . . . . . . . . . . . 7

Task 2: Noninvasive Boron Quantification . . . . . . . . . . . . . . . . 7

Task 3: Real-Time Measurement Dosimetry Research . . . . . . . . . . . . . . . . 7

Task 4: Analytical Dosimetry ......................... 7

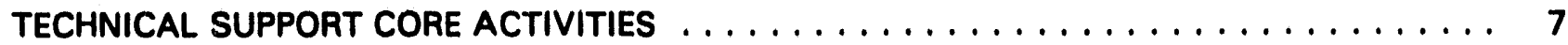

Task 1: Inductively Coupled Plasma-Atomic Emission Spectroscopy (ICP-AES)

Analyses of Boron in Biological Samples . . . . . . . . . . . . . 7

Task 2: Boron Compound Purity Determinations . . . . . . . . . . . . . 8

Task 3: Intra- and Intercellular Boron Analyses $\ldots \ldots \ldots \ldots \ldots \ldots \ldots$

Task 4: Neutron Beam Measurement Dosimetry . . . . . . . . . . . . . . . . . . . . . 8

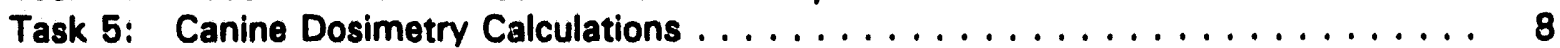

Task 6: BNCT Database Management System . . . . . . . . . . . . . . . . . . . . 9

Task 7: Georgia Tech Research Reactor Physics Support . . . . . . . . . . . . . . . 10

Task 8: Research Reactor/Accelerator Physics Support . . . . . . . . . . . . . . . 10 


\section{FIGURES}

1. Comparison of carcinoma, melanoma and normal fibroblasts ability for boron uptake

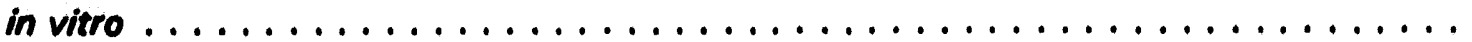

2. In vitro comparison between B16-BL6 melanoma and Lewis Lung carcinoma for preferential incorporation

3. The preference of the liposome in Lewis Lung carcinoma. Normal fibroblasts do not appear to readily take up this liposome encapsulated

4. BMRR ellipsoid phantom irradiation 


\section{ACRONYMS AND ABBREVIATIONS}

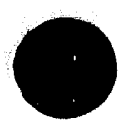

\begin{tabular}{|c|c|}
\hline BMRR & $\begin{array}{l}\text { Brookhaven Medical Research } \\
\text { Reactor }\end{array}$ \\
\hline BNL & $\begin{array}{l}\text { Brookhaven National } \\
\text { Laboratory }\end{array}$ \\
\hline BNCT & $\begin{array}{l}\text { Boron Neutron Capture } \\
\text { Therapy }\end{array}$ \\
\hline BPA & Boronophenylalanine \\
\hline BSH & $\begin{array}{l}\text { Borocaptate Sodium } \\
\left(\mathrm{Na}_{2} \mathrm{~B}_{12} \mathrm{H}_{1}, \mathrm{SH}\right)\end{array}$ \\
\hline CT & Computed tomography \\
\hline GHRH & $\begin{array}{l}\text { Growth hormone releasing } \\
\text { hormone }\end{array}$ \\
\hline GIT & $\begin{array}{l}\text { Georgia Institute of } \\
\text { Technology }\end{array}$ \\
\hline HRP & Horseradish peroxide \\
\hline ICP-AES & $\begin{array}{l}\text { Inductively coupled plasma- } \\
\text { atomic emission spectroscopy }\end{array}$ \\
\hline INEL & $\begin{array}{l}\text { Idaho National Engineering } \\
\text { Laboratory }\end{array}$ \\
\hline ISU & Idaho State University \\
\hline i.v. & Intravenous \\
\hline LDL & Low density lipoproteins \\
\hline MRI & Magnetic resonance imaging \\
\hline NMJ & Neuromuscular jünction \\
\hline OCRH & $\begin{array}{l}\text { Ovine corticotropin releasing } \\
\text { hormone }\end{array}$ \\
\hline TLD & Thermoluminescent dosimeter \\
\hline WSU & Washington State University \\
\hline
\end{tabular}




\section{INEL BNCT RESEARCH PROGRAM MARCH/APRIL 1993}

\section{INTRODUCTION}

This report contains an overview of progress for the Idaho National Engineering Laboratory (INEL) Boron Neutron Capture Therapy (BNCT) Research Program for March/April 1993, including Information on the Research Programs, Technical Support Details, and Miscellaneous Project Information.

The following sections are the reports from the various investigators about their current research.

\section{BORON DRUG DEVELOPMENT}

Carboranyl Alanine and Low-Density Lipoprotein (LDL) Development and Evaluation

No report for this period.

\section{Boronated Liposome Development and Evaluation}

Compound Development: As part of the effort to produce lipophilic boron compounds for liposomal bilayer embedment, distearyl carborane, 9,12-( $\left(\mathrm{C}_{10} \mathrm{H}_{37}\right)_{2} \mathrm{C}_{2} \mathrm{~B}_{10} \mathrm{H}_{10}$, has been synthesized and isolated. Degradation of this carborane derivative with $\mathrm{KOH} / \mathrm{EtOH}$ produced the dicarbollide anion $\mathrm{K}\left(5,6 \cdot\left(\mathrm{C}_{10} \mathrm{H}_{37}\right)_{2} \mathrm{C}_{2} \mathrm{~B}_{9} \mathrm{H}_{10}\right]$ in high vield. This species is of particular interest to the liposome project since this compound is, in essence, a lipid mimic. The two stearyl chains should pack efficiently within the distearylphosphatidylcholine:cholesterol bilayer employed in previous experiments. The anionic carborane head group imparts negative charge on the exterior of the vesicle which appears to increase the tumor specificity of the liposomes.

Starting materials have been synthesized for the investigation of the reactivity of $\left(\mathrm{B}_{20} \mathrm{H}_{10}\right)^{4 \cdot}$ with oxalyl chloride. Preliminary investigations suggested that the expected product, $\left[\mathrm{B}_{20} \mathrm{H}_{17} \mathrm{CO}^{3}{ }^{3}\right.$, could be formed. Problems due to isomerization were encountered earlier and hindered the complete investigation of the reaction at that time. The $\left[\mathrm{B}_{20} \mathrm{H}_{17} \mathrm{CO}\right]^{3 \cdot}$ ion could prove to be as useful a synthon as $\left[\mathrm{B}_{10} \mathrm{H}_{8} \mathrm{CO}\right]$; , and additional offort has been directed at its production.

Liposome Encapsulation and Development: Three liposomal suspensions and one free compound have been sent to Vestar, Inc. for murine biodistribution experiments in the EMT6 tumor line. These are identified as follows:

1. Liposomes encapsulating $\mathrm{Na}_{3} \mathrm{~B}_{20} \mathrm{H}_{1}$, that also contain $\mathrm{K}\left(\mathrm{C}_{2} \mathrm{~B}_{9} \mathrm{H}_{11}\left(\mathrm{CH}_{2}\right)_{18} \mathrm{CH}_{3}\right]$ in the lipid bilayer,

2. Liposomes encapsulating $\mathrm{Na}_{3} \mathrm{~B}_{20} \mathrm{H}_{17} \mathrm{NH}_{3}$ that also contain $\left.\mathrm{K} \mathrm{C}_{2} \mathrm{~B}_{2} \mathrm{H}_{1},\left(\mathrm{CH}_{2}\right)_{18} \mathrm{CH}_{3}\right]$ in the lipid bilayer,

3. Liposomes embedding the new doubletalled lipophilic compound, $\mathrm{K}\left(\mathrm{CH}_{3}\left(\mathrm{CH}_{2}\right)_{17}\right]_{2} \mathrm{C}_{2} \mathrm{~B}_{0} \mathrm{H}_{10}$, and

4. A suspension of reo $\mathrm{K}\left(\mathrm{C}_{2} \mathrm{~B}_{0} \mathrm{H}_{1},\left(\mathrm{CH}_{2}\right)_{18} \mathrm{CH}_{3}\right]$.

The murine experiments have been completed. Results are pending.

Liposomes described by items 2 and 3 above have also been sent to Washington State University (WSU) for murine biodistribution experiments in the Lewis Lung tumor-line. These murine experiments have been completed. Results are pending.

Liposomes described by item 2 above have also been sent to WSU for initial experiments in rats bearing intracranial implanted brain tumors.

\section{Pituitary Tumor Evaluation}

Experiments desioned to demonstrate corticotropin receptor dependent AtT-20 cell demise via BNCT have been carried out at Oregon 
Health Sciences University. AtT-20 cells were incubated with elther ovine corticotropin releasing hormone (OCRH), oCRH conjugated to enriched carborane cage ( ${ }^{10} \mathrm{~B}_{10}-\mathrm{CRH}$ ), or ${ }^{10} \mathrm{~B}_{10^{\circ}}$ CRH plus excess oCRH. This paradiom represents a classic competition experiment designed to block the ${ }^{10} \mathrm{~B}_{10}$-CRH AtT-20/BNCT cell offect. Cells were incubated at $37 \mathrm{C}$ for 10 minutes under the three conditions above, washed with phosphate buffered saline, and subjected to the thermal column noutron beam for three minutes at full power (1 MW). Cells were then removed from the thermal column, washed, and cultured in 6-well plates for colony counting 14 days later. AtT-20 cell colonies from colls incubated with ${ }^{10} \mathrm{~B}_{10}$-CRH were significantly lower in number than from cells incubated with oCRH alone. However, when cells were incubated with ${ }^{10} \mathrm{~B}_{10}$ - $\mathrm{CRH}$ plus excess CRH, this decrease was elliminated, such that the number of colonies of this group were similar to the cells incubated with CRH alone. These date suggest that the BNCT effect observed in our studies with the releas. ing factor CRH as the boron carrier in AtT-20 cells is CRH receptor mediated, and not due to a nonspecific effect. These experiments will be repeated to validate the results.

Experiments using growth hormone releasing hormone (GHRH) as the boron carrier and $\mathrm{CH}_{3}$ pituitary somatotroph tumor cells are currently on-going. Specificity of CRH for its receptor and/or GHRH for its receptor and the ability of these releasing hormones to modulate BNCT cell death are also on-going.

Human cancer cells, representing malignant molanoma, breast cancer, prostate cancer, pancreas cancer, and meningioma neoplasias, are currently available in our lab. New hormonal boron carriers are being synthesized to test the efficacy of BNCT on a variety of endocrine mediated and hormone responsive malignancies.

\section{BORON LOCALIZATION SCREENING}

Boronophonylalanine (BPA) Evaluation
Studies

BPA offlux studies have been completed. Collular and supernatant concentrations of BPA have been evaluated over a time course to determine BPA efflux. Cell pellets and supernatant samples have been sent to INEL for boron analysis. Results are pending and, upon recolpt, will be incorporated into a manuscript which is currently in preparation.

\section{LDL Studies}

In Vive Sareening: LW-1-55 \& LW-1-67: Evaluation of these boronated LDLs has been completed using BDF mice bearing B16-BL6 melanoma. Tissue and blood samples have been sent to INEL for analysis. Results are pending.

In Vitre Screening: LW-1-83: Murine B16-BL6 melanoma, murine Lewis Lung carcinoma, rat RG2 olioma, U87MG human glioma, and one normal control cell line (murine mammary fibroblasts) were used. Cell pellets and supernatant samples have been sent to INEL for boron analysis. Results are pending.

LW-1-51: Three different cell lines were used: murine Lewis Lung carcinoma, B16-BL6 molanoma and normal murine flbroblasts (Figure 1 ). Data analysis indicated that boron levels were highest at 24 hours in the Lewis Lung carcinoma, averaging $22 \mu \mathrm{g} / \mathrm{gm}$ pellot.

LW-1-55: B16-BL6 melanoma and murine LeWis Lung carcinoma cells were used for this comparison (Figure 2). Data indicate that Lewis Lung carcinoma showed more uptake than melanoma. Maximum boron levels found in the melanoma were determined to be $5.0 \mu \mathrm{g} / \mathrm{gm}$ cell pellet at 12 hours, whereas, the maximum amount found in the carcinoma was determined to be $8.0 \mu \mathrm{g} / \mathrm{am}$ cell pellet at 24 hours.

\section{Luposome Evaluation Studies}

In Vive Screening: $\mathrm{K}+\left[\mathrm{C}_{2} \mathrm{~B}_{0} \mathrm{H}_{10}\left(\left(\mathrm{CH}_{2}\right)_{17} \mathrm{CH}_{3}\right)_{2}\right]^{\circ}$ lembedded in the lipid bilayerl. $\mathrm{K}+\left[\mathrm{C}_{2} \mathrm{~B}_{0} \mathrm{H}_{10}\left(\left(\mathrm{CH}_{2}\right)_{17} \mathrm{CH}_{3}\right)_{2}\right]^{\circ}$ (embedded in the lipid bilayer) and $\mathrm{Na}_{3} \mathrm{~B}_{20} \mathrm{H}_{1}, \mathrm{NH}_{3}$ (liposome encapsulated) were screened in vivo for boron uptake using C57 mice bearing Lewis Lung carcinoma. Tissue and blood samples have been sent to INEL for boron uptake analysis. Results are pending for both of these compounds.

$\mathrm{Na}_{2} \mathrm{~B}_{20} \mathrm{H}_{18}:$ Balb/C mice bearing P1 798 lymphosarcoma were used for this evaluation study. 


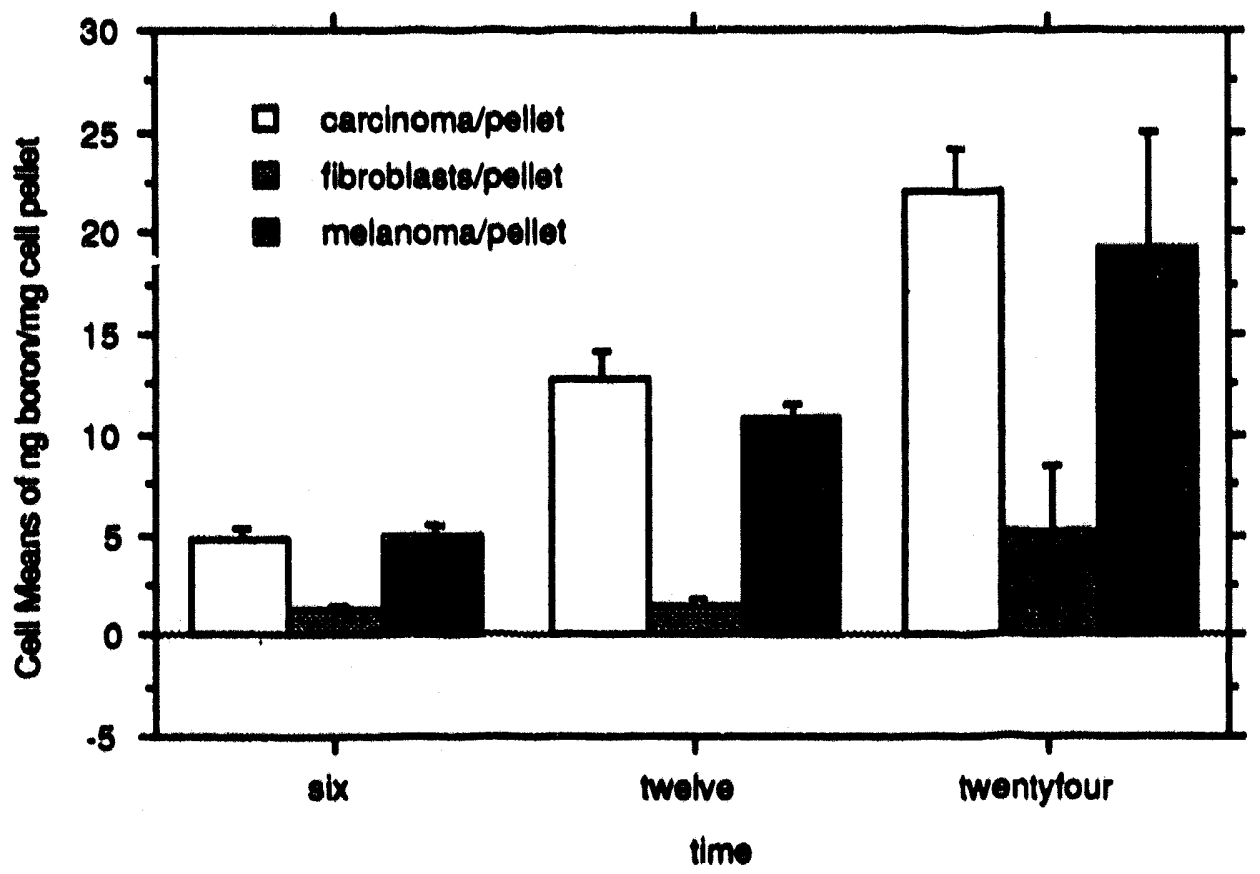

Floure 1. Comparison of carcinoma, melanoma and normal fibroblasts ability for boron uptake in vitro.

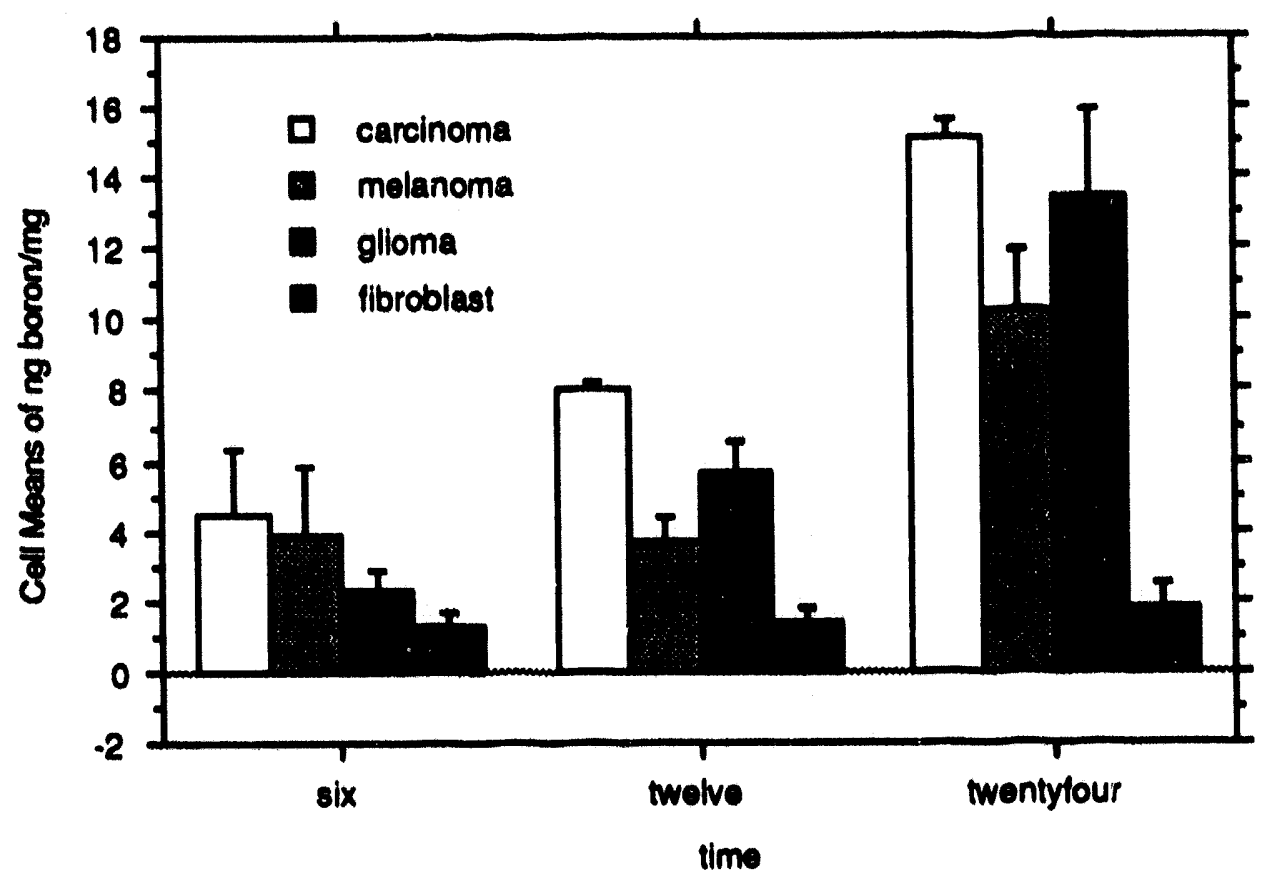

Figure 2. In vitro comparison between B16-BL6 melenoma and Lewis Lung carcinoma for preferential incorporation of boronated LDL. 
Tumor-to-blood ratios were found to be highest at 72 hours (7.6:1). Boron levels in the liver peaked at 6 hours averaging $107.2 \mu \mathrm{o} / \mathrm{am}$ tiesue. The maximum average concentration found in the tumor occurred at 18 hours 123.4 po/om tissuel.

$\mathrm{Na}_{2} \mathrm{~B}_{10} \mathrm{H}_{0} \mathrm{NCO}: \quad \mathrm{CD}_{2} \mathrm{~F}_{1}$ mice bearing P1798 Iymphosarcoma were used to ovaluate this liposome encapsulated compound. Boron lovels were maximum in the tumor at 6 hours with an average concentration of $11.5 \mathrm{\mu g} / \mathrm{gm}$ tissue. The highest level of boron in the blood occurred at 6 hours, averaging $18.8 \mu \mathrm{g} / \mathrm{gm}$.

$\mathrm{K}+\left(\mathrm{C}_{2} \mathrm{~B}_{2} \mathrm{H}_{11}\left(\mathrm{CH}_{2}\right)_{10} \mathrm{CH} 3\right\}^{\prime}: \mathrm{CD}_{2} \mathrm{~F}_{1}$ mice bearing Lowis Lung carcinoma were used to ovaluato this compound which has been embedded into the liposome bllayer. Bafore screening this compound was determined in vitro to be noncytotoxic. In vivo evaluation showed that with multiple injections, maximum tumor-toblood ratio of 3.6:1 at the 72 hour time point could be reached. Blood boron levels peaked at $26.9 \mathrm{\mu g} / \mathrm{gm} 6$ hours after liposome injection. Maximum tumor boron levels occurred at 12 hours with an everage value of $23.3 \mathrm{\mu o} / \mathrm{am}$ tissue.

$\mathrm{K}+\left[\mathrm{C}_{2} \mathrm{~B}_{0} \mathrm{H}_{1},\left(\mathrm{CH}_{2}\right)_{10} \mathrm{CH} 3\right\}^{\circ}$ lombedded in lipld bilayer) ans $\mathrm{Na}_{3} \mathrm{~B}_{20} \mathrm{H}_{1}$ (liposome encapsulated): C57 mice bearing Lewis Lung carcinome were used in the in vivo evaluation of this compound. Average maximum boron levels in the liver were calculated to be $245.97 \mathrm{\mu g} / \mathrm{gm}$ tissue at the $\mathbf{7 2}$ hour time point for the multiple injection group. Tumor-to-blood ratio was at its highest at 72 hours $(1.3: 1)$.

In Vitre Sareening: $K+\left[\mathrm{C}_{2} \mathrm{~B}_{0} \mathrm{H}_{1},\left(\mathrm{CH}_{2}\right)_{18} \mathrm{CH} 3\right]^{\circ}$ were ovaluated using B16-BLG melanoma, Lewis Lung carcinoma and normal fibroblast cell lines. Results showed that B16-BL6 molenoma incorporate $\mathrm{K}+\left(\mathrm{C}_{2} \mathrm{~B}_{6} \mathrm{H}_{1},\left(\mathrm{CH}_{2}\right)_{18} \mathrm{CH} 3\right)^{\prime}$ more readily than the carcinoma. Normal fibroblasts boron concentrations were found to be negligible. For B16-BL6 malanoma the maximum concentration of boron was $24 \mu \mathrm{g} / \mathrm{gm}$ pellet at 24 hours postinoculum.

$\mathrm{K}+\left(\mathrm{C}_{2} \mathrm{~B}_{0} \mathrm{H}_{11}\left(\mathrm{CH}_{2}\right)_{18} \mathrm{CH} 3\right)^{-}$(embedded in the lipid bilayerl and $\mathrm{Na}_{3} \mathrm{~B}_{20} \mathrm{H}_{1}$ (liposome encapsulated): were evaluated using B16-BL6 melanoma, Lewis Lung carcinoma, rat RG2 glioma and normal fibroblast cell lines and analyzed by INEL for boron uptake. Boron levels were higheat at 24 hours in the Lewis Lung carcinoma having an average value of $15.1 \mathrm{\mu g} / \mathrm{gm}$ pellot. Normal fibroblasts did not readily take up this boronated compound (Figure 3).

$\mathrm{Na}_{2} \mathrm{~B}_{20} \mathrm{H}_{10}$ : Analysis of this liposome encapeulated compound using B16-BL.6 molanoma, rat RG2 glioma, Lowis Lung carcinoma and normal murine fibroblast cell lines has been completed. Levels of boron peaked at $C$ hours in the rat gliome with an average concentration of 1.2 $\mu \mathrm{g} / \mathrm{om}$ pollot. In comparison, normal fibroblasts concentratione were highest at 12 hours having an average concentration of $1.3 \mu \mathrm{o} / \mathrm{om}$ pellot.

\section{DRUG STABILITY. PHARMACOLOGY AND TOXICITY}

\section{Toxicological Evaluation of Borocaptate Bodtum (BSH)}

For several months, Idaho State Univeralty (ISU) researchers have been reporting that intravenous (i.v.) infusion of BSH la particularly lethal when administored to rats instrumented for measurement of cardlovascular function. The most recent studies indicate that for instrumented rats, I.V. administration of BSH doses as low as $150 \mathrm{mg} / \mathrm{kg}$ can cause death. Such doses are not lethal in noninstrumented rats, and instrumented rats infused with salline instead of BSH remain robust for the duration of the six hour experiment. Last month, it was hypothesized that this BSH-instrumentation interaction may indlcate toxic synergism between BSH actions on the heart and an instrumentation-induced activation of the sympathetic automic nervous system. This interaction was postulated to potentiate BSH. induced arrhymogenesis, which in turn caused cardiovascular collapse and death. To test this hypothesis, we pretreated instrumented animals with $\beta$-adrenergic (propranolol) and $\alpha$ adrenergic (phenoxybezamine) antagonists prior to administration of BSH. If sympathotic activation was sensitizing the heart to the offects of BSH, inen blocking the receptors mediating this activation should prevent the low dose BSH lethality observed in instrumented rats. However, suppression of sympathetic 


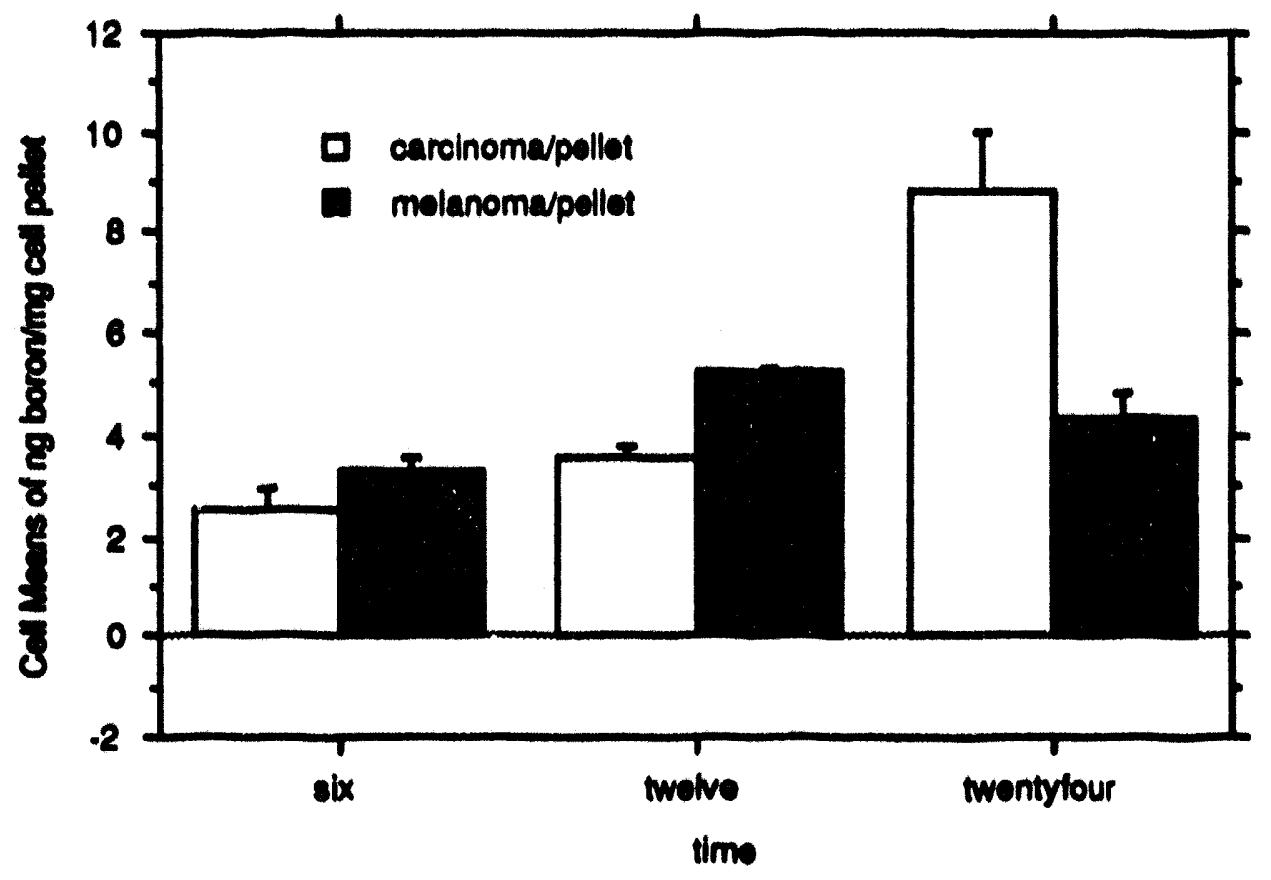

Figure 3. The proforence of the liposome is Lewis Lung carcinoma. Normal fibroblasts do not appear to readily take up this liposome encapsulated compound.

function failod to antagonize the lethal effect of low-dose BSH injected into the instrumented rats. The failure of the hypothesis to predict this results invalidates the hypotheais and rules out a role for aympathetic activation. The one caveat to this conclusion is that if BSH binds and inactivates the B-antagonist, this test of the hypothesis would be invalid. Studies on BSH-nouromuscular junction blocker interac. tions (below) suggest that this may be occurring. ISU researchers are currently dotermining how best to evaluate this possibility.

ISU researchers have also reported that i.v. injection of BSH rapidly and effectively reverses respiratory paralysis induced by the neuromus. cular junction (NMJ) blocking drug, gallamine. Recent experimentation indicates that BSH also reverses the effects of a second NMJ blocking drug, pancuronium. Gallamine triethlodide (15 mg/kg) or pancuronium bromide $(2 \mathrm{mg} / \mathrm{kg})$ adminiatered by I.v. to Long Evans rats caused prolonged skeletal muscle paralysis and respira. tory fallure. In the absence of artificial respiration, these doses of NMJ blockers were fatal. If artificially respirated, however, rate recovered within 45 to 60 minutes. BSH $175.200 \mathrm{mg} / \mathrm{kg}$. i.v., rate: $28 \mathrm{mg} / \mathrm{kg} / \mathrm{min}$ ) was infused 5.16 minutes after full NMJ blockade was establishod. Rate regained their ability to sponteno. ously breathe almost immediately after the start of BSH infusion, indicating a BSH-induced reversal of the skelotal muscle paralysis induced by the NMJ blockers. BSH infusion reastablished a normal respiratory pattorn, and stable cardiovascular function was maintained throughout the time period that control rats (NMJ antagonist without BSH) remained paralyzed. The rapld, effective and sustained reversal of resplratory paralysis by BSH sug. gests that this drug might be a usoful antidoto for treating overdosage of NMJ blockers. It also ralses the specter that BSH may be altering the function of nicotinic cholinergic receptors. If so, this could be of toxicological signiffcance, since this receptor type mediates nu- 
merous phyelologleally important functions in both the peripheral and central norvous syetems. An alternative explanation for the BSH antagoniam lo that BSH may be acting as : "chomical sponge", binding the quaternary NMJ blocking drugs, and preventing them from interecting with the recoptor sites. If such chemical binding is indeed occurring, it emphsalzes the need to botter ovaluate and undorstand potential BSH-drug intoractions. Exportmonts to improve our understanding of thase NMJ blocker.BSH interactions are undorway.

\section{TREATMENT PROTOCOL DEVELOPMENT}

\section{Large Animal Modal Studios}

Phnrmuagkination: No additional dogs have been infused.

Normnl Trenun Tolerance (Nhutron Irradintion): Brookhaven National Leboratory (BNL) was assiated with irradiation of thoir BPA-fructose dogs. Four dogs wore irradiated the first part of March, with a two hour watt post infualon and then 15 minute irradiation. Three dogs in - sacond oroup were irradiated the latter part of March, with a 80 minute wat post infusion and then $\mathbf{7 0 . 7 5}$ minute irradiation.

Three dogs, at $28 \mathrm{ppm}$ and $19 \mathrm{~Gy}$, had their 12 month post irradiation checkups. The computed tomography (CT) and magnotic resonance imaging (MRII scans revealod no changes. Afterwards the dogs were euthanized and necropsled.

Two doge, at $25 \mathrm{ppm}$ and $27 \mathrm{~Gy}$, had thoir 18 month post irrediation checkups. The CT and MRI scans revealed no changes.

Elght dogs were irradiated during March. Two doge were irradiated with blood boron concentrations of $70.100 \mathrm{ppm}$ to noutron dose 36.42 Gy. One dog was Irradiated with blood boron concentration of $40.60 \mathrm{ppm}$ to a noutron dose of $30.40 \mathrm{~Gy}$. One dog, split dose done over two consecutive days, was irradiated with blood boron concentration of $25 \mathrm{ppm}$ to a noutron dose of $13.5 \mathrm{~Gy}$ both days for a total neutron dose of $27 \mathrm{~Gy}$. Four dogs underwent akin reflection auroery and were irradiated to a dose of 15 Gy with no BSH.

At this time there are no clinical abnormalitios attributable to irradiation treatment.

Gopontannounlvaogaurrina Brnin Tumor Doon: Three potential candidates wore seen at WSU during March and April. On further oveluation all three of these dogs were ruled out as possiblo brain tumor treatment candidates. ITwo doges did not have tumors; one dog dled bofore diagnostic workup could be instituted.)

"Crystal" Ard (1135447-164), a five year old spayed fomale Malamute cross, had surgery to remove a large meninglome from the right frontal lobe on Fobruary 24. Three and a hatf weeke later, "Crvatal" underwent imradiation treatment at BNL. She was treated with 101 ppm blood boron concentration to a dose of 31.2 Gy. "Crystal" is clinically very much improved following treatment with only some minor proprioception doficte remaining. Sho returned home two weeks post treatment and then returned for a three weok post treatment MRI. The three weok post MRI scan rovealed an area of enhancement which is belioved surgery related.

"Dudley" Fisot ("136447-151), an elght year old castrated Golden Rotrlover, is doing oreat.

"Brandy" Hoff ("135447-94), an elght year old spayed female Golden Rotriover, is doing oreat. "Brandy" will be returning to WSU in June for her three and a half year post treatment checkup.

\section{Phyclologlod Response Evaluation and Interdiction}

The remarkable result of BNCT's selective brain tumor ablation is reported in the paper titled "Truly Solective Brain Tumor Ablation by Boron Neutron Capture Therapy in Rat $9 \mathrm{~L}$ Gllosarcoma." This represents the joint work with Jeff Coderre in which single BNCT schedules were utillzed. The paper will be submitted to the International Journal of Radiation Oncol. ooy, Biolooy. Physics for publication in a spacial BNCT issue, probably in late 1983 or early 1994. A copy of the complote manuscript as submitted will be sent with the next progress report (May-Juno). 
BNCT Frnationntion Ssudv - Part Lli Elght rat brains have been received from BNL and processed for horseredish peroxide (HAP) histochomiatry. All of the brains have been sectioned. Approximately $75 \%$ of the data has been collocted and the data analysis is $50 \%$ complote.

ENCT Frnationation Studv - Partll: Twelve rat braine have been recelved and $30 \%$ of the processing for HAP histochamistry has been comploted at this time. The work le proceeding on the remaining brains and the date acquialtion will be starting when the processing is complete.

Ganine BNCT Studv-Pant: Soven dog brains were recelved. To date, all of this tiasue has been sectioned; approximately $50 \%$ has undergone date acquisition. This is progressing slowly due to the lack of funding.

Canine BNCT Studv - Part lli Two containers of tissue have been received. They appear to contain vight brains. The tissue is waiting for processing. This is progressing slowly due to the luck of funding.

\section{SUPPORTING TECHNOLOGY DEVELOPMENT}

\section{Task 1: Blochemistry of BSH and Its Oxi-} dation Products

No progress to report for this period.

\section{Task 2: Noninvadve Boron Quantfication}

To aid in the analysis of brain tumor transport in a canine gliosarcoma model via gadolinium enhanced proton magnetic resonance imaging. University of Utah researchers have been ovaluating methods for measuring spin-lattice relaxation (TI) using serially doped gadolinium phantoms in the clinical GE Signa scanner. In mid May actual tracking of gadolinium penetration into an implanted and growing tumor will provide information on the rate of blood-brain. barrier breakdown which relates to penetrability of BNCT agents.
Tack 3: Real-TIme Meseurement Dosimotry Research

No progrese to report for this period.

\section{Tack 4: Analytical Dodimotry}

Irentment Plinning Softwere: The rtt_MC Monte Carlo radiation transport module was modified to incorporate an improved interpola. tion scheme in the edit routinas. It MC auto. matically provides region edite and 3-dimen. sional voxal edits during a run. Point, line, surface, and volume edits can then be obtained for regions of interest by interpolution within the voxel space. The voxul edits are exact, providing flux and dose, integrated over each voxel. A plot, for example a line plot, of the voxel data provides a histogram shape. To obtuin better reproduction of the true shape, intra-voxel interpolation must be performed. For the initial version of the edit routines, simple linear interpolation was performed with weighing functions for nolghboring voxels. This scheme was found to be poor at the edges of the edit space and did not always reproduce the true volume integral. The new scheme uses a quadratic interpolation and the constraint that integration over any volume exactly reproduces the true volume integral. This preserves flux and dose oradients at the edges of the edit space. This scheme was implemented and found to be a significant improvement over the old method.

TECHNICAL SUPPORT CORE ACTIVITIES

Task 1: Inductively Coupled PlasmaAtomic Emission 8pectroscopy (ICP-AEs) Analyees of Boron in Blological Samples

The Fisions/ARL Model 3520 ICP-AES was out of service due to some problems in the monochromator which now have been fixed.

Freezer space is currently at a premium and all samples provisously recoived, and researchere that have submitted samples for analysis must decide if the wish to retain samples for which 
they already have results. The decision should also be made whether there is any need to do any analysis on samples that they do not have results for.

\section{Samples Received $=911$ \\ Samples Prepared for Analysis $\quad=\quad 919$ \\ Samples Analyzed $\quad=\sim 1157$ \\ Backlog: \\ Awaiting Preparation $\quad=-4131$ \\ Blood, Liver, Spleen, \& Tumor $=-628$ \\ Other - Brain, Skin, Muscle, \\ Kidney, etc. \\ $=\sim 2698$ \\ Prepared, Awaiting Analysis \\ Tack 2: Boron Compound Purity Determinations}

No new boron compounds were received during this period.

Task 3: Intra- and Intercellular Boron Analyses

No progress to report for this period.

\section{Task 4: Neutron Beam Measurement Dosimetry}

During March 8-12, four Labrador cross dogs were irradiated at the Brookhaven Medical Research Reactor (BMRR) filtered beam port for dose tolerance purposes. These dogs were infused with BSH at levels 25 to $80 \mathrm{ppm}$. The $25 \mathrm{ppm}$ dog was irradiated to $2700 \mathrm{cGy}$ in two fractions of $1350 \mathrm{cGy}$ each with BSH, separated by 24 hours.

Also INEL WSU personnel provided dosimetry and veterinary services during this period for four Beagle irradiations for BNL.

During March 22-26, four reflected scalp dogs and one client dog were irradiated. Again, dosimetry and veterinary support was provided for three beagles irradiated for BNL.

Two INEL personnel traveled to the High Flux Reactor at Petten, The Núcherlands, the week of April 19-23, to make neutron spectrum and dosimetry measurements in the plastic beagle and cylinder phantoms. The liquid Argon filter at Petten has been modified to improve the epithermal beam characteristics. The purpose of the trip was to repeat the measurements

made in 1991 to determine the extent of beam improvement.

A summary of the Petten irradiation follows. Neutron flux values will be reported later.

1. Indium inside boron sphere $(2 \mathrm{hr})$ - Fast Neutron Flux (E > 1 MeV).

2. Beagle Head Phantom (15hr) - Thermal and epithermal neutron flux distribution.

3. Beagle Head Phantom (1 hr) - Gamma dose distribution.

4. Spectrum Wheel (3hr) - Epithermal Neutron Flux $(0.50 \mathrm{~V}<E<10 \mathrm{keV})$.

5. Cylindrical Phantom (15hr) - Thermal and epithermal flux distributions.

6. Cylindrical Phantom (1hr) - Gamma dose distributions. Compare thermoluminescent dosimeter (TLD) 400 response with TLD 700 response.

7. Cylindrical Phantom (1hr) - Compare dark and light irradiations of TLD 400's.

8. Uranium-235 inside boron sphere (15hr) Fast Neutron Flux (E > $1 \mathrm{keV}$ ).

9. Indium inside boron sphere (15hr) - Fast Neutron Flux (E> 1MoV).

Total irradiation hours: 70.

Total number of wires and foils irradiated and analyzed: 90.

\section{Task 5: Canine Dosimetry Calculations}

BMRR Supporti Calculations were performed with the rtt_MC Monte Carlo sntiware to compare with INEL measurements tor the BNL ellipsoid phantom (Figure 4). The phantom was irradiated in the BNL epithermel beam with no delimiter in place. The comparison for neutron flux is shown in Figure 4. BNL has also performed measurements and calculations for this phantom. The BNL and INEL mothods were completely independent and results were in quite good agreement. 


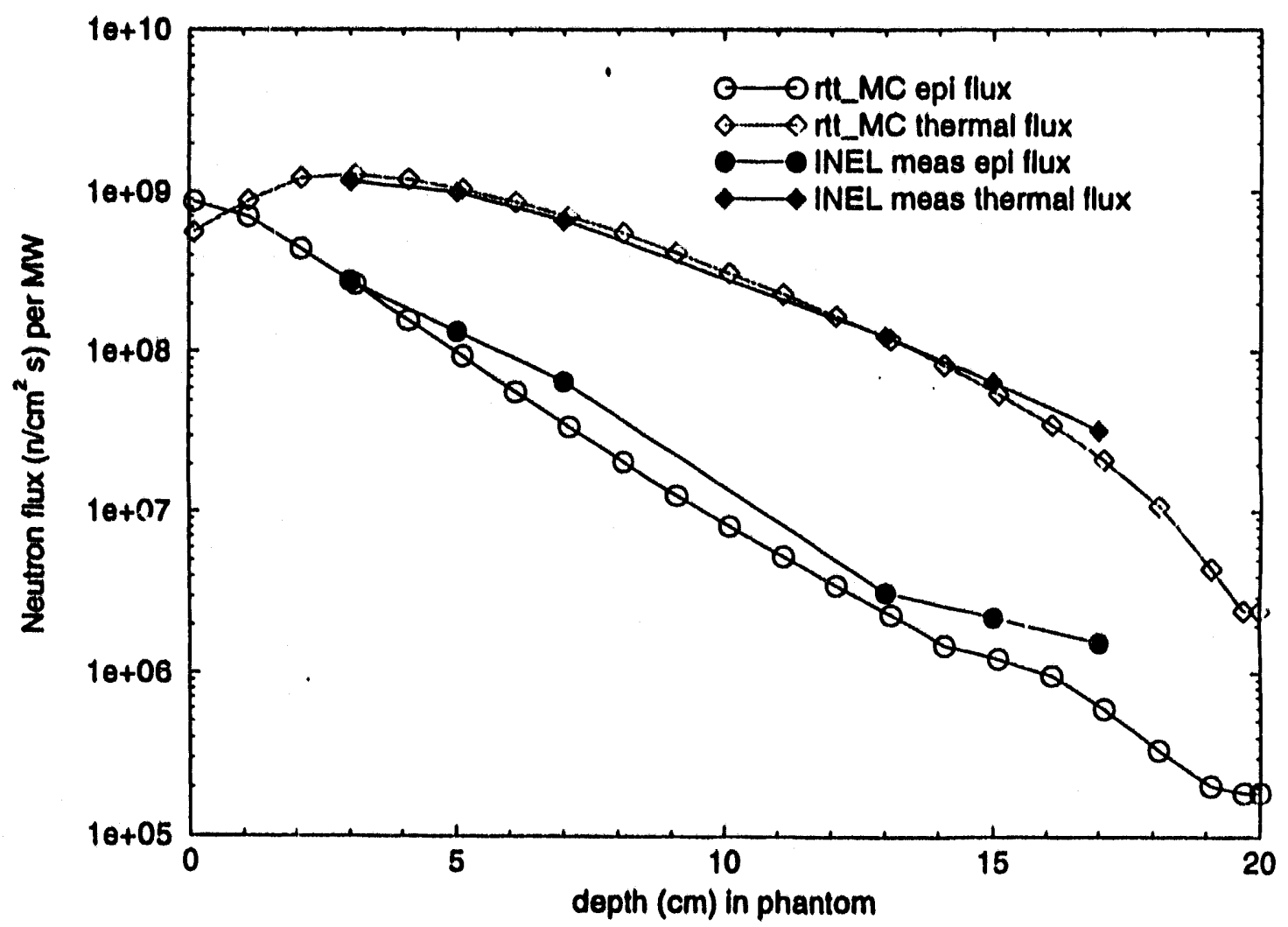

Calculation and measurement errors: The statistical error in the Monte Carlo calculation varies from approximately $1 \%$ (standard deviation) at the peak values to about $10 \%$ at the $10 \mathrm{~cm}$ depth. The uncertainties in the measured values are estimated to be $10 \%$ or less.

Figure 4. BMRR ellipsoid phantom irradiation, measured and calculated results.

Dose rates were calculated for one client dog with a debulked tumor, and for the reflected scalp surgery dogs. It was dissired to calculate these dose rates using the b-spline geometry capabilities of rtt_MC. However, unforeseen complications in producing an appropriate model from either MRI or CT images required using combinatorial geometry primitives to build the model for the client dog and scaling the bspine model of a smaller Labrador imaged at the University of Utah for the surgery dogs. Calculations to determine dose rates for both the client dog and the surgery dogs ivere performed using the newest rtt_MC software.

The capability to read CT images generated on the GE 7800 (upgraded to 8800 ) on the WSU campus would be beneficial to the program due to both time and cost contiderations. David Reddy of Radiologic, Inc. is currently working on this problem. The lack of available docu- mentation on the 7800 format has slowed progress.

Calculations have been performed in support of rat irradiations at BNL in the thermal port of the BMRR. Thermal flux and dose have been calculated for various irradiation configurations. Preliminary calculated results, coupled with the physiological response reported in the January/February 1993 issue of the INEL BNCT Research Program report, indicate that an relative biological effectiveness dose of $60 \mathrm{~Gy}$ to the hippocampus may not be possible without inducing a fatal nasopheryngeal radiation response.

\section{Task 6: BNCT Database Management System}

Database development and data entry continue at WSU. 
Task 7: Ceorgla Tech Research Reactor Physics Support

Calculations continue to be performed to validate the design of the Georgia Institute of Technology (GIT) filter design. The MCNP model has been obtained from GIT and is being run on EG\&G's computer system. Comparison of the two calculations will be discussed with GIT researchers.

Tack 8: Research Reactor/Accelerator Physics Support

No progress to report for this period. 

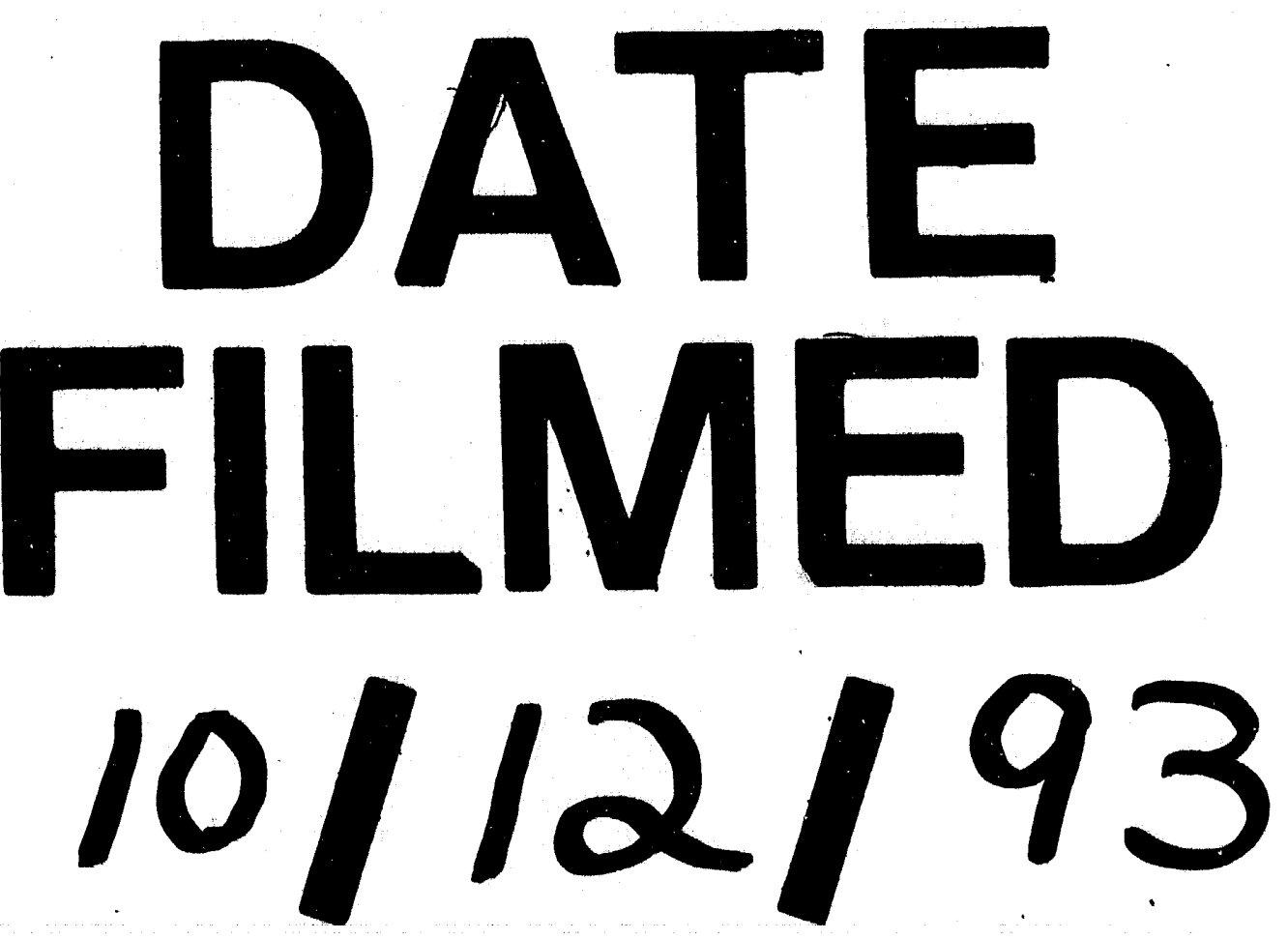
